\title{
ACADEMICIAN GHEORGHE DUCA - THE SCIENTIST WHO LIVES THE PRESENT BY LEARNING FROM THE PAST AND INVESTING IN THE FUTURE
}

Gheorghe Duca's great love for science, for the people which he works with, for his country and for this nation comes from his vast universal knowledge that he gathered from the most important scientific centers of the world.

(Acad. Eugen Doga, R. Moldova)

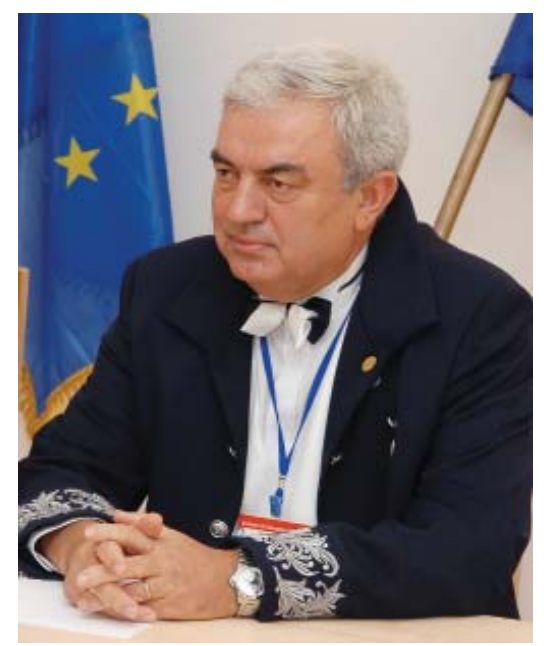

It is our privilege to give a special dedication to the Editor-in-chief of Chemistry Journal of Moldova and our colleague, Academician Gheorghe Duca, who stands at the origins of the Journal. Our appreciation and admiration for the renowned scientist, pedagogue and public person, Gheorghe Duca, descends from the certitude that he is a pioneer and an impassioned animator in the field of his scientific activity - Ecological Chemistry. Through his research work, initiatives and especially his visions, Acad. Gheorghe Duca is, indisputably, a Personality of European value. As the founder of the scientific school of Ecological Chemistry in Republic of Moldova, he developed the theory of redox phenomenon in the environment, the ecological audit methodology and formulated the basic principles of environmental education. Under the supervision of Acad. Gheorghe Duca many disciples became accomplished specialists, including $4 \mathrm{DSc}$ and $22 \mathrm{PhD}$. The scientific results of Acad. Gheorghe Duca are reflected in more than 70 books, 150 patents and about 1000 scientific papers. Through the initiatives of Acad. Gheorghe Duca, Republic of Moldova got the reputation of an international scientific center in the field of Ecology. Under the leadership of Acad. Gheorghe Duca five editions of Ecological Chemistry conferences were organized in Chisinau.

In the early 2000s Moldovan science experienced stagnation. Moldovan state funded the science just to a survival level causing the intensive migration of researchers from scientific institutions, including Academy of Sciences of Moldova. A new concept in research and innovation branch was needed. In that difficult period, in the leading position of the Academy of Sciences of Moldova was elected young Acad. Gheorghe Duca. A new era began in the development of science and technology. Acad. Gheorghe Duca contributed to the revival and modernization of research: development and promotion of the Code for Science and Innovation of Republic of Moldova, which contributes to strengthening the scientific forces and democratization of science.

Scientific, teaching and managerial contribution of Acad. Gheorghe Duca was appreciated at home as well as abroad, being awarded many honorific titles, such as: Emeritus scientist (1996); State Prize in Science and Technology (1998, 2004); Medal “Dimitrie Cantemir” (2002); Order “Labour Glory” (2007); National Award GALEX (2011); Order of the Republic (2011); Award of The Romanian Academy (2012); Award for outstanding achievements in the field of EIECO - Black Sea (2013); Medals "Henri Coanda" and Mihai Eminescu, Romania (1997, 2014); Knight of the Order for Inventions of the Kingdom of Belgium (2003); "The Cross of Commander of the Order of Honour", Poland (2004); Gold Medal "for Eminent Services to the cause of progress", Brussels (2005); Gold Medals "I.P. Pavlov", “N.S. Kurnakov” and “B.I. Blinikov”, Russian Federation (2004, 2007, 2008); International Socrates Award, Oxford, UK (2009); Silver Medal of the Association of Innovators of China (2010); Gold Medal "EUROINVENT”, Brussels (2011); the Order “The crown of Romania” with the rank of Commander (2015).

Clairvoyance, erudition, sacrifice, courage, creative initiatives, insight, openness to universality always characterized the Personality of exceptional scientist and manager - Academician Gheorghe Duca.

Academician Aurelian GULEA Coordinator of the Exact and Natural Sciences Department, Academy of Sciences of Moldova

Corresponding member Tudor LUPASCU Director of the Institute of Chemistry of ASM, Editor of Chemistry Journal of Moldova 